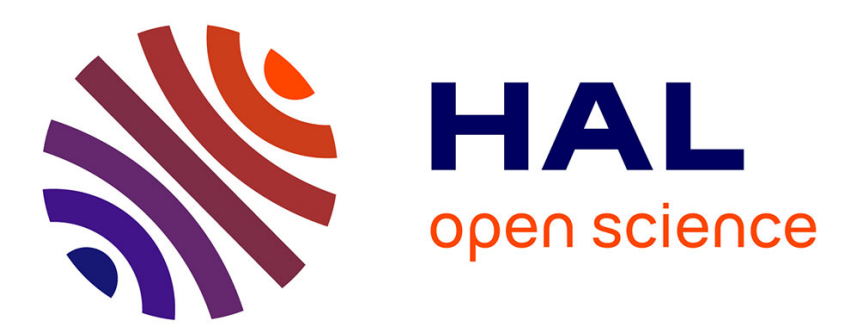

\title{
The Role of Networks for Helping Firms and Countries Invent New Competitive Strategies Well Adapted to the World Knowledge Economy
}

Camille Baulant

\section{- To cite this version:}

Camille Baulant. The Role of Networks for Helping Firms and Countries Invent New Competitive Strategies Well Adapted to the World Knowledge Economy. Journal of Economic Issues, 2015, 49 (2), pp.563-573. 10.1080/00213624.2015.1042804 . hal-01392751

\section{HAL Id: hal-01392751 \\ https://hal.science/hal-01392751}

Submitted on 26 May 2021

HAL is a multi-disciplinary open access archive for the deposit and dissemination of scientific research documents, whether they are published or not. The documents may come from teaching and research institutions in France or abroad, or from public or private research centers.
L'archive ouverte pluridisciplinaire HAL, est destinée au dépôt et à la diffusion de documents scientifiques de niveau recherche, publiés ou non, émanant des établissements d'enseignement et de recherche français ou étrangers, des laboratoires publics ou privés. 


\title{
The Role of Networks in Helping Firms and Countries Invent New Competitive Strategies Adapted to the World Knowledge Economy
}

\author{
Camille Baulant
}

\begin{abstract}
For the last twenty years, the world economy has evolved at a great speed. Every good, capital asset, and knowledge is mobile and induces more competition. Innovation in commodities is a complex process that requires more cooperation. To innovate in the knowledge economy, firms nowadays must establish "win-win situations" for individuals in creating networks. These networks are useful for firms in order to come up with innovative strategies. The building of networks enables the interactions between agents, the environment, and institutions. The interdependence of agents and institutions is not new to evolutionary theory (Commons 1931; Veblen 1898). However, I argue that institutions must be more flexible than ever before in order to help agents adapt to the modern knowledge economy. On the basis of the role of meso-networks, I propose new long-run specialization and short-run competitiveness that will promote greater efficiency and equality around the world in relation to firms and countries exporting industrial goods into world markets. Within the innovative networks, I analyze the role of two different actors: (i) the "economic leader" who has a long-run strategy and (ii) the "go-between leader" who knows how to diffuse "useful information" to actors to help them innovate in new products, services, or processes.
\end{abstract}

Keywords: competitive advantage, information competitiveness, learning networks, lobbying network, meso-institution

JEL Classification Code: F40, L14, L16

Camille Baulant is a professor of international economics at the University of Angers, and the director of a Master Degree in Business Intelligence and Competitive Strategies, GRANEM Laboratory, Angers (France). The author is grateful to Gemma Davies, researcher assistant at the Granem Laboratory of the University of Angers, for helping improve the English of this paper. She also thanks Fatme Myuhtar-May for her carefully reading and correcting the final manuscript. She acknowledges the constructive comments of Christine Ngoc Ngo during the session "Business Enterprise, Market Governance, and the Social Provisioning Process" of the 2015 AFEE meeting in Boston. The author pays homage to Frederic S. Lee who gave her the opportunity to discover the social provisioning process. 
For the last twenty years, the world economy has been evolving with a great speed. Every good, capital asset, and knowledge is mobile and induces rising competition. The knowledge economy stimulates more cooperation with the division of cognitive labor (DCL) process. The interdependence between individuals and institutions is an old question to evolutionary theory (Commons 1931; Veblen 1898), but rising competition and cooperation are among the challenges that firms must face today, when innovating and selling on the world markets. Two opposite approaches have been recently proposed for firms in order to increase their market shares on the world markets. The "strategic approach of economics" insists on the increasing role of "competition" to win the actual "economic war" (Baumard 2012; Harbulot 2014). In this approach, building "knowledge networks" authorizes the seizure of "strategic knowledge." On the other hand, the "institutional approach of economics" stresses the endogenous characteristics of the "learning by sharing" process to reach an efficient level for both individuals and collective organizations (Cohendet, Creplet and Dupouët 2000; Foray 2000).

I argue that these opposite approaches must be mixed into dynamic networks, where institutions are as important as markets and demand policies are as useful as supply policies in increasing innovations in countries. In the first section of the paper, I analyze why it is so important to build "meso-institutions" for thinking and acting in the new economy. In the second part, I propose new long-and short-run strategies, based on dynamic networks, pertinent to both firms and countries. In the last section, I study two new functions that are useful for managing individuals and organizations within these networks.

\section{Division of Cognitive Labor and Networks Organization Within Firms}

The globalization of countries and their entry into a knowledge economy induce a contradictory movement of "competition" and "cooperation" between individuals, firms, and countries. Facing these quantitative and qualitative changes in the world economy, both previous regulation mechanisms - the "invisible hand" of private markets and the "visible hand" of the national institutions of nation states - have failed to allow the adaptation of firms to the new kind of competition. The interdependences between markets and institutions in the economic growth of countries have been studied for a long time in evolutionary theory. Among these analyses are those of Thorstein Veblen (1898), Karl Polanyi ([1944] 1983), Albert Hirschman (1970), and Frederic S. Lee (2013), to name a few. In thinking dynamic interactions between markets and institutions, Edgar Morin (1977 [1981]) and Arthur Koestler (1988) have already shown how an "intermediary institution" in systemic approaches could be more powerful than the "macro-institution" of the nation state. The meso-institutions, created by individuals within firms or countries, stabilize the behaviors of individuals (by producing "regularities by disorder") and create innovation (by producing "complexity by disorder") (Atlan 1979). John S. Brown and Paul Duguid (1991) as well as Patrick Cohendet, Frédéric Creplet and Olivier Dupouët (2000) demonstrate how flexible meso-institutions (as the "communities of 
practice") must be today in order to help individuals adapt their strategies to the knowledge economy. In a global "inclusive economy," ${ }^{1}$ it is important to conceptualize the contradictory relationships between markets and institutions, supply and demand, internal and external environment. From a systemic analysis perspective, firms and countries must be "open" to innovation and "constraint" by "path dependency" to produce and sell on the market. A traditional debate in economics proposes two opposite approaches to managing this evolution. On one side, the "market approach" - based on the methodological individualism - focuses on the "automatic go-back to the equilibrium." On the other side, the "institutional approach" - based on the holistic approach - centers on the "co-evolution of markets and institutions" inside the "path dependency" of a firm or country. ${ }^{2}$

To study more profoundly the consequences of global change on the behavior of firms, my analysis stresses the utility of building networks by individuals (Table 1). Today, this meso-institution seems more efficient than the micro-level of private firms or macro-institutions (which suffered from the decreasing power of nation states in international relationships). In the modern knowledge economy, innovation becomes a "collective" process and the relationships between individuals become as important as each inventive component (Guilhon and Levet 2003; Muldoon 2013). The DCL concept is so far away from the "international division of industrial labor" - one, where big international firms choose to implant different activities, such as research, raw materials, producing, and selling, in different countries. With the high economic growth rate of the 1990s and the 2000s, the place of new industrialized countries (NIC) in the world markets have increased both quantitatively (they now belong to G20 and G8) and qualitatively (they also enter into the knowledge economy). The most important "emerging countries" are competing against advanced countries in goods and services with the use of high technology. So, in order to define the new "sustainable competitive advantage specialization," all countries must analyze their specialization "on the whole value chain" (Aghion et al. 2005; Porter 1990). To build their long-run strategy, firms must exploit the interdependences that exist between supply, demand, cooperation, and competition. If these links are not sufficiently thought through, firms would fail to adapt to the world market changes. On the other hand, anticipating new innovation requires the creation of meso-networks to interlink cooperation and competition. In determining future demands for goods, countries compete on the world market. The competition among countries, not only concerns the "upstream business" (cost-intensive technologies pertaining to aerospace, planes, energy sectors, medicine), but also the "downstream business" (intensive in

${ }^{1}$ The "social provisioning process," as defined by Lee (2013), stresses the following main qualitative factors in analysing the "inclusive economy": incorporation of caring and wellbeing of agencies; global analysis (economic, political, and social processes); the key role of ethical values; and analysis of the variety of agents who are involved in the production and consumption process.

2 Svetlana Kirdina (2014) analyzes the interactions of "revolution" with "social evolution" in different countries. The "path-dependency evolution" depends on the interaction of "individual" and "communitarian" values in different spheres (economic, political, and ideological). 
inexpensive technology like low-cost computer industries or new information and communication technologies (ICT).

Table 1. Consequences of the Two Main World Changes on External Competition and Internal Organization of Firms

\begin{tabular}{|c|c|c|c|}
\hline Factors & $\begin{array}{l}\text { Macro-nation-states political } \\
\text { approach (1815) }\end{array}$ & $\begin{array}{l}\text { Micro-international firms } \\
\text { economic approach (1990) }\end{array}$ & $\begin{array}{l}\text { Meso-institution networks } \\
\text { ecological approach (2000) }\end{array}$ \\
\hline \multirow{2}{*}{ World changes } & Goods liberty & Capital assets liberty & Knowledge liberty \\
\hline & Int. labor division & Int. industrial division & Cognitive labor division \\
\hline Environment & & & Rare \\
\hline Inform & Lack of & Over-info & Lack of useful in \\
\hline \multirow{2}{*}{ Analysis } & $\begin{array}{c}\text { Dual invisible hand } \\
\text { Market/Welfare states }\end{array}$ & & Systemic: learning networks \\
\hline & Hard power nation states & $\begin{array}{c}\text { Soft power belief, value, } \\
\text { preference }\end{array}$ & $\begin{array}{l}\text { Smart power organized } \\
\text { proximity }\end{array}$ \\
\hline \multirow{3}{*}{$\begin{array}{l}\text { Organization } \\
\text { nature in private } \\
\text { firms }\end{array}$} & Price competition & Monopolistic competition & "Coopetition" \\
\hline & Hierarchic leader & Transactional leader & Transformational leaders \\
\hline & $\begin{array}{c}\text { Top down (firms) learning } \\
\text { by doing }\end{array}$ & $\begin{array}{l}\text { Down up (consumers) } \\
\text { learning by using }\end{array}$ & $\begin{array}{l}\text { Co-building (shareholders) } \\
\text { learning by sharing }\end{array}$ \\
\hline
\end{tabular}

\section{Long- and Short-Run Strategies for Building Meso-Networks}

\section{How Firms Create Networks for Building Sustainable "Competitive Advantages"}

In this section, I study the role of networks to create a long-run competitive advantages for small firms. With the globalization of the world economy, the optimal specialization strategy has changed, too. Today, most countries specialize in sectors that produce high value goods, so the competition for producing such goods has sharply increased since 1990. However, the "non-price specialization," proposed by Elhanan Helpman and Paul Krugman (1985) for advanced countries, is no longer sufficient to explain the countries' choices of specialization. "Emerging countries" represent a rising part of the actual world trade and they know how to compete with advanced countries. Since 2001, China has increased its patent deposits in the highly innovation intensive "industrial goods," while India is exporting high technology "computer services" and Brazil trades in biotechnological goods that are $R \& D$ intensive.

To help understand the actual strategies of firms, I expand on the "competitive advantage" theory of Mickael Porter (1990). The innovation process must include the

Brazil exports "intelligent textile goods" that combine "cotton" with "spider's genes" to make textile elastic and resistant. 
specific role of "market innovation." In recombining some previously invented "radical innovations" into new products Apple Inc., for example, has succeeded in answering the new "needs" of consumers. So, I introduce into Porter's "diamond" the concept of "differentiation" for analyzing the different strategies of firms, which combine supply, demand, competition, and cooperation factors (Figure 1). My concept of "differentiation" allows all small firms to participate in "market innovations." The aim of innovations is taking into account the "real needs" of consumers in particular markets. Within the networks, firms build systemic interrelations between opposite factors to reach an output that will be "more than the sum of its parts" (Koestler 1988). Most small firms develop their competitive advantage by achieving some "market innovations." For example, since most of India's population still lives on limited income, Indian firms practice more "frugal innovations" (i.e., Tata Nano, iPpad, Smartphone, or 3D printer to build houses) than "radical innovation" (i.e., aerospace or pharmaceutical products) to build competitive advantages (Prahalad and Hammond 2002). In order to build "competitive advantages," small firm must invent new "cooperation relationships." Cooperation could be simple and simply based on a tacit sharing process. This kind of cooperation uses low-cost investments, such as, for example, the purchase of a cell phone for communicating and selling products. Finally, firms must invent new ways to practice "competition" in using different kinds of competitiveness for increasing their market shares, as shown in the next section.

Figure 1. Using Meso-Networks to Co-Build Long-Run Competitive Advantages for Small Firms

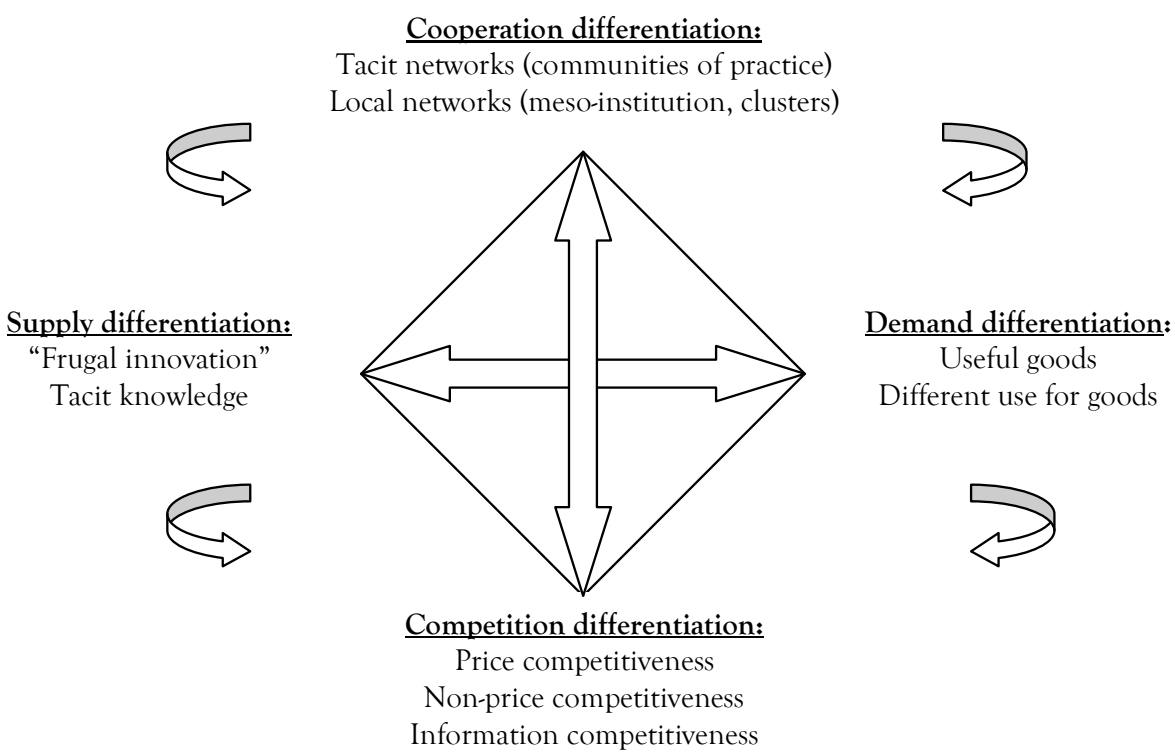


In the world market, firms must manage three kinds of competitiveness: "price competitiveness," "non-price competiveness," and "information competitiveness." This information competitiveness becomes more important because of the ICT revolution. Today, a "false information" can destroy the reputation of a firm even if their products are of good quality. In order to be "pro-active" in the world markets, all firms engaged in "business intelligence." The methodology of the business intelligence is to transform "information" into "knowledge" and then to transform "knowledge" into "useful information." Information competiveness is thus quite different from price competiveness (to have low prices), as well as from non-price competitiveness (to develop their oligopolistic positions).

To increase their market shares in the world market, firms can use the three kinds of proactive meso-networks that support information competitiveness. Here I present, as a long-run strategy, the case of small firms that can use the power of these networks. On one side of the competitiveness triangle (Figure 2), the "sharing networks" are useful for firms to initiate some cooperation between all partners. On the other side, the "positive lobbying networks" are used by firms to explain to their partners how their products are better than their competitors'. At the summit of the triangle are the "institutional networks." They are useful because the co-building institutions are able to change as quickly as economic rules in the world markets. These intermediary institutions (industrial patents organizations, non-governmental organizations, regional councils, etc.) help small firms to patent industrial innovations. Intermediary organizations can also inform small firms about a new change in international norms or laws. Even if small firms are not powerful enough to change the existing law, they can adapt their products to new norms before other competitors. As all firms today must be "proactive" in the world market, the mesonetworks are particularly efficient in increasing the power of small firms.

\section{How to Manage Meso-Networks Inside and Outside Companies}

Changes in the world market have involved new strategies based on dynamic networks. The co-building of these networks is based on private markets and institutional regulations. Today, national institutions are not powerful enough to regulate the new economy, where everything moves quickly. Building mesoinstitutions constitutes an opportunity to challenge competition and build cooperation relationships. I apply Geoffrey M. Hodgson's (2006) definition of

A research conducted by Ronald A. Hites et al. (2004), published in Nature, concluded in 2004 that Norwegian salmon was more cancerous than salmon from North America. This information, largely diffused by media, subsequently caused a 40 percent decrease in the sales of Norwegian salmon on the French market, even after this information was corrected by further scientific studies.

While business intelligence is not new (Ansoff 1975; Wilensky 1967), business intelligence practices have sharply increased since 1990 , with the end of the Cold War. 
Figure 2. Using Meso-Networks to Raise Short-Run Information Competitiveness of Small Firms

Meso-institutional networks differentiation:

Protect immaterial knowing

Crowd-funding institutions

Diffuse international norms or laws

\section{Sharing networks}

differentiation:

Learning by doing

Learning by using

Learning by sharing

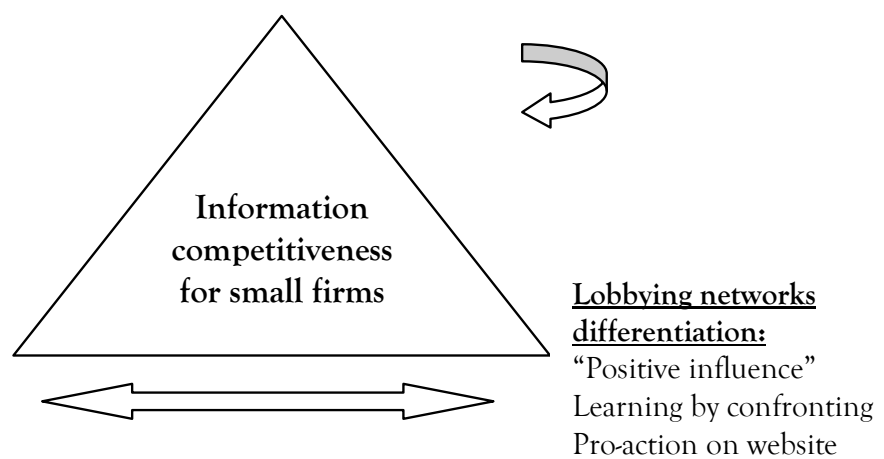

"institution" (in Ülgen 2014) to the reality of the knowledge economy. It holds that "the institution can be defined as systems of established and prevalent social rules that structure social interactions in order to make them compatible with the survival of a given society" (Hodgson in Ülgen 2014, 577). With the DCL, social institutions become "intermediary institutions" (as community of practice, clusters, and cooperatives) that help agents adapt to new environments. These new institutional networks are important in stabilizing the behavior of firms. They also help firms create dynamic "strengths-weaknesses opportunity threat" (SWOT) by transforming threats into opportunities. To build dynamic SWOTs, firms must create some "organized proximity," defined by Alain Rallet and André Torre $(2005,49)$ as "the capacity to encourage individuals to interact." Organized proximity "helps" individuals work together, but also "constraints" them (Rutherford 2009). Here, I analyze how "organized proximity" permits the co-building of intermediary networks. For creating efficient "organized proximity" within a network, two kinds of leaders must be identified: the "economic leader" and "go-between leader." Whereas the former conducts a long-run strategy, the latter diffuses "useful information" to the right agents at the right moment (Table 2).

\section{"Economic Leaders" Conduct the Long-Run Strategy}

In organized networks, the systemic interrelations between individuals and organizations are not sufficient to generate innovations. Different works in sociology and management (Avolio and Bass 1991; Drown and Duguid 2000) explain how recent changes in the world economy transformed regulation from a "hierarchic 
Table 2. Consequence of the Two World Changes on the Long-Run Specialization and the Short-Run Competitiveness of Firms

\begin{tabular}{l|c|c|c}
\hline Strategies & Macro (1815) & Micro (1990) & Meso (2000) \\
\hline Free trade agreement & Goods & Capital assets & Knowledge \\
\hline Labor processes & Int. labor division & Int. industrial division & Cognitive labor division \\
\hline $\begin{array}{c}\text { Long-run strategies } \\
\text { advantage theory }\end{array}$ & $\begin{array}{c}\text { Non-price advantage } \\
\text { theory }\end{array}$ & $\begin{array}{c}\text { Competitive advantage } \\
\text { theory }\end{array}$ \\
\hline $\begin{array}{l}\text { Short-run } \\
\text { competitiveness }\end{array}$ & $\begin{array}{c}\text { Price } \\
\text { competitiveness }\end{array}$ & $\begin{array}{c}\text { Non-price } \\
\text { competitiveness }\end{array}$ & $\begin{array}{c}\text { Informational } \\
\text { competitiveness }\end{array}$ \\
\hline $\begin{array}{l}\text { Organization in } \\
\text { firms and network }\end{array}$ & Hierarchic leader & Transactional leader & $\begin{array}{c}\text { Economic leader } \\
\text { go-between leader }\end{array}$ \\
\hline \hline
\end{tabular}

leader" into a "transactional leader," proposing rewards for individuals in order to increase their efficiency. Since 1990, the "transactional leader" had also changed into a "transformational leader" (Karaszewski and Lis 2013; Muller and Pénin 2006, 7). This "transformational leader" co-builds a common strategy wherein all issues are discussed by all partners in the network (Kotter 2007). Here, I analyze what the minimum factors are for defining an efficient "economic leader." From the studies on different experiments of cluster organizations in different countries (Amisse et al. 2008; Baulant 2007), I find that the "economic leader" must have two main characteristics. First, the "economic leader" must be a "visionary," capable of seeing into a thirty-year horizon. Second, the "economic leader" must be able to stabilize the cooperation relationships. Thus, the "economic leader" must make sure that all participants of his/her network would really "obtain an advantage" by cooperating out of his/her own motivation. In such a configuration, the people who are involved in networks are looking to cooperate for co-building a new strategy, and, therefore, would not engage in a "free-riding behavior." So, the "economic leader" does not have to monitor all the actions of his/her partners because he/she trusts them. As individuals feel both linked with other indviduals and have autonomy within the network, they are very motivated to co-build the collective strategy.

\section{"Go-Between Leaders" Manage the Short-Run Strategy}

The work of the "go-between leader" (the "gate keeper" of Crozier 1977) is also very important to the successful building of meso-networks. This leader constructs a kind of "alchemy" among employees, whereby the whole would become greater than the sum of its parts in the network. Getting different people to work together within the network is the "go-between leader's" role, and it is complementary to the 
"economic leader's" one. The "go-between leader" knows how to make use of the network's "weak ties” (Granovetter 1973). When some partners of his/her network refuse to cooperate, the "go-between leader" must negotiate compromises. In practice, the "go-between leader" must understand how people with different goals and cultures can cooperate. He/she has to formulate some "intermediary goals" that are useful in order to reach the final goal presented by the "economic leader." The "economic leader" builds organized proximity in the network by using the individuals' capacity to build "new norms" together. The "go-between leader" also builds organized proximity in the network by using the capability of individuals to share the "same frame of mind" (Rallet and Torre 2005). To keep the network active, the "gobetween leader" is proactive in helping people communicate and cooperate (see the "nudge" analysis of Thaler and Sunstein [2008] 2010). This function within the network is paramount, even if society seems to give the "go-between leader" less consideration than to the "economic leader."

\section{Concluding Notes}

Rising globalization and the knowledge economy have led to an uncertain world. In such a world, the firms must use proactive networks to sustain their innovation strategies, as well as their competitiveness practices. To manage these long- and shortrun strategies inside the firms, I discussed two kinds of leaders: "economic leaders" and "go-between leaders." Whereas the "economic leader" conducts the innovation strategy, the "go-between leader" manages the producing and selling strategy. The networks organization of firms induces new regulation policies that are far removed from the "top down hierarchy." Effectively, networks must be flexible enough to be both open to innovations (by monitoring, for example) and closed to internal objectives and cultural habits in order to induce learning outcomes. Managing innovative and selling networks is a hard task. As these networks have powerful leverage in building "virtuous circles" of economic growth, firms have to concentrate their efforts on controlling some "key points" of their network and allowing a degree of liberty to each individual within the network. My analysis stresses the key role of the differentiation process within the meso-networks in innovating and competing. This study reconciles the two opposite approaches in economics: the strategic vision of competition and the participative vision of innovation. Further research should explore these new ways of "thinking the complexity" and "acting efficiently" by taking into account not only economic and quantitative efficiency, but also social and qualitative efficiency. The main objective would be to define a new regime of

In the knowledge economy, the leaders are "hill-climbers on an unknown landscape." The "maverick leader" (i.e., the "economic leader") "discover[s] new land" and the "follower leader" (i.e., the "go -between leader") explores this new land in detail (Muldoon 2013, 125).

The concept of "bounded rationality," created by Herbert Simon and Dominique Foray (2000), shows how Michel Crozier (1977) played a "go-between leader" role in diffusing this concept in France. 
economic growth and a new way of consuming, based on the concept proposed by Joseph E. Stiglitz, Amartya Sen, and Jean-Paul Fitoussi (2008) of the "Gross Product Happiness" index, which seems more adapted to the world knowledge economy than the "Gross Domestic Product" index.

\section{References}

Aghion, Philippe, Nick Bloom, Richard Blundell, Rachel Griffith and Peter Howitt. "Competition and Innovations: An Inverted-U Relationship.” Quarterly Journal of Economics 120, 2 (2005): 701-728.

Amisse, Sylvain, Camille Baulant, Paul Muller and Amanda Vargas. "The Concept of Cluster and Its Two Logics.” EAEPE Conference Labor, Institution in a Global Knowledge Economy, Rome, Italy, November 6-8, 2008.

Ansoff, H. Igor. "Managing strategic surprise by response to weak signal." California Management Review 18, 2 (1975): 21-33.

Atlan, Henri. Entre le cristal et la fumée: Essai sur l'organisation du vivant. Paris, France: Seuil, 1979.

Avolio, Bruce J. and Bernard M. Bass. The Full Range of Leadership Development: Basic and AdvaNced Manuals. Binghamton, NY: Bass, Avolio and Associates, 1991.

Baulant, Camille. "De l'Europe des nations à l'Europe des régions: l'intérêt de l'approche des clusters pour relancer la coopération européenne." Bilan et perspective d'un demi-siècle de construction de l'Union Européenne dans le cadre de la mondialisation économique contemporaine, pp. 170-185. Warsow, Poland: Warsow University Press, 2007.

Baumard, Philippe. Le vide stratégique. Paris, France: CNRS Éditions, Janvier, 2012.

Brown, John S. and Paul Duguid. "Organizational Learning and Communities of Practice: Towards a Unified View of Working, Learning and Innovation.” Organization Science 2 (1991): 40-57.

Cohendet, Patrick, Frédéric Creplet and Olivier Dupouët. "Organisational Innovation, Communities of Practice and Epistemic Communities." In Economics with Heterogeneous Interacting Agents, edited by Alan Kirman and Jean-Benoît Zimmermann, pp. 303-326. Heidelberg, Germany: Springer Verlag 2000.

Commons, John R. "Institutional Economics.” American Economic Review 21, 4 (1931): 648-657.

Crozier, Michel. L'Acteur et le Système. (In collaboration with Erhard Friedberg). Paris, France: Le Seuil, 1977.

Foray, Dominique. L'économie de la connaissance. (Collection Repères No.302.) Paris, France: La Découverte, 2000.

Granovetter, Mark S. "The Strength of Weak Ties.” American Journal of Sociology 78, 6 (1973): 1360-1380.

Guilhon, Bernard and Jean-Louis Levet. (Sous la direction.) De l'Intelligence Economique à l'économie de la connaissance. Paris, France: Edition Economica, 2003.

Harbulot, Christian. Techniques offensives et guerre économique. Paris, France: Editions La Bourdonnaye, 2014.

Helpman, Elhanan and Paul Krugman. Market Structure and Foreign Trade. Cambridge, MA: MIT Press, 1985.

Hirschman, Albert. Exit, Voice, and Loyalty: Responses to Decline in Firms, Organizations, and States. Cambridge, MA: Harvard University Press, 1970.

Hites, Ronald A., Jeffrey A. Foran, David O. Carpenter, M. Coreen Hamilton, Barabara A. Knuth and Steven J. Schwager. "Global Assessment of Organic Contaminants in Farm Salmon." Nature 303, 5655 (2004): 226-229.

Hodgson, Geoffrey M. “What Are Institutions?” Journal of Economic Issues 40, 1 (2006): 1-25.

Karaszewski, Robert and Andrzej Lis. "The Role of Leadership to Stimulate Pro-Developmental Positive Organisation Potential.” In Positive Management: Managing the Key Areas of Positive Orgnisational Potential for Company Success, edited by Marek Torun and Jacek Stankiewicz, pp. 59-88. Poland, 2013.

Kirdina, Svetlana. "Institutions and the Importance of Social Control in a Nation's Development." Journal of Economics Issues 48, 2 (2014): 309-322.

Koestler, Arthur. Génie et folie des l'homme, le cheval dans la locomotive (le paradoxe humain). Paris, France: Calman-Levy, 1988. 
Kotter, John P. "Leading Change: Why Transformation Effort Fails." Harvard Business Review (January 2007):96-103.

Lee, Frederic S. "Competition, Going Enterprise, and Economic Activity." In Alternative Theories of Competition: Challenges to the Orthodoxy, edited by James K. Mouded, Cyrus Bina and Patrick L. Mason, pp. 16-173. London: Routledge, 2013.

Morin, Edgar. La méthode : la nature de la nature, tome 1. Paris, France: Le Seuil [1977] 1981.

Muldoon, Ryan. "Diversity and the Division of Cognitive Labor." Philosophy Compass 8/2 (2013): 117-125.

Muller, Paul and Julien Pénin. "Why Do Firms Disclose Knowledge and How Does It Matter?" Journal of Evolutionary Economics 16, 1-2 (2006): 85-108.

Polanyi, Karl. La Grande Transformation: aux origines politiques et économiques de notre temps. Bibliothèque des sciences humaines. Paris, France: Gallimard, [1944] 1983.

Porter, Mickael. "Competitive Advantage of Nations." Harvard Business Review (March-April 1990): 73-91.

Prahalad, Coimbatore K. and Allen Hammond. "Serving the World's Poor, Profitably." Harvard Business Review 80, 9 (2002): 48-57.

Rallet, Alain and André Torre. "Proximity and Localization." Regional Studies 391 (2005): 47-59.

Rutherford, Malcolm. "Toward a History of American Institutional Economics." Journal of Economics Issues 43, 2 (2009): 309-318.

Stiglitz, Joseph E., Amartya Sen and Jean-Paul Fitoussi. Commission sur la mesure des performances économiques et du progrès social. Paris, France: July 25, 2008.

Thaler, Richard H. and Cass R. Sunstein. Nudge, la méthode douce pour inspirer la bonne décision. Paris, France: Collection Pocket, Editions Vuibert, [2008] 2010.

Ülgen, Faruk. "How to Guide the Economy in a Socially Desirable Direction: Lessons from the 2007 financial turmoil." Journal of Economics Issues 48, 2: (2014): 575-584.

Veblen, Thorstein. "Why Is Economics Not an Evolutionary Sciences?" Quarterly Journal of Economics 12, 2 (1898): 373-397.

Wilensky, Harold L. Organizational Intelligence: Knowledge and Policy in Government and Industry. New York, NY: Basic Books, 1967. 